\title{
Cystic Fibrosis Serum Effects on Rabbit Tracheal Epithelium: an Ultrastructural Analysis
}

\author{
JOHN R. KENNEDY AND PATRICIA L. ALLEN ${ }^{(26)}$ \\ Department of Zoology. University of Tenenssee, Knoxville. Tennessee, USA
}

\begin{abstract}
Summary
The major variation in effect between undiluted cystic fibrosis and heterozygote sera on rabbit tracheal epithelium was in terms of the time after exposure at which changes occurred. Exposure to both types of sera for 3 min caused release of goblet cell mucus and ciliary resorption possibly by apical swelling of columnar cells. Fusion of cilia and loss of microtubule pairs increased markedly through $60 \mathrm{~min}$ exposure. After $60 \mathrm{~min}$ exposure to heterozygote sera, a thick mucus net formed over many regions of the ciliary surface trapping cilia. Cilia from these areas showed separation occurring between adjacent pairs of peripheral microtubules with individual microtubule pairs remaining intact. Prolonged exposure $(60 \mathrm{~min})$ to cystic fibrosis serum resulted in increased mucus secretion and massive columnar cell loss. Some columnar cells were extensively swollen and basal cells showed significant changes. Control serum had no effect on tracheal epithelium over the same time span. Such cystic fibrosis serum-induced changes are characteristic of what one would expect from cells undergoing extensive cytolysis and are much more severe than those induced by heterozygote sera.
\end{abstract}

\section{Speculation}

A component in cystic fibrosis serum may alter membrane regulation resulting in increased levels of intracellular calcium in ciliated and goblet cells. This increase may account independently for ciliary alterations and mucus secretion which ultimately cause ciliary dyskinesia. Prolonged calcium influx may account for the cytolysis of epithelial cells. Comparable factors may be responsible for mucus stagnation and respiratory dysfunction in patients with cystic fibrosis.

In 1969, Spock et al. (21) reported that serum from cystic fibrosis patients, but not from control individuals produced ciliary dyskinesia (a disorganized ciliary beat) in rabbit tracheal explants. Conover et al. (9) utilizing a modification of Spock's system confirmed serum induced dyskinesia after 3 to $6 \mathrm{~min}$ exposure for both cystic fibrosis and heterozygote sera. Bowman et al. (5) described similar serum effects on oyster gill cilia. This latter assay used cessation of ciliary beat as the endpoint as opposed to ciliary dyskinesia.

However, not all reports indicated that cystic fibrosis serum was ciliotoxic. Christensen and Norrevarg (8), using fresh oyster and rabbit tracheal tissue, were unable to demonstrate dyskinesia differences between cystic fibrosis serum and normal serum. Posselt and Bender (18), using fresh-water mussels, also observed variation in effect. Ciliary beat persisted in some cases after $6 \mathrm{hr}$ exposure, and in several cases $24 \mathrm{hr}$ exposure, to all types of sera. Cherry et al. (6) using rabbit and chicken tracheal explants, reported ciliotoxicity from all sera after $30 \mathrm{~min}$ exposure. Examinations by light microscopy showed extensive destruction to the epithelial layer, associated with eosinophilic degradation of the cytoplasm.
Bogart et al. (4) reported ultrastructural changes in rabbit trachea after 6 min exposure to cystic fibrosis and control serum. Cell damage increased with both sera, suggesting a generalized cytolytic effect. No alterations in ciliary structure were reported which might account for previously described changes in the pattern of ciliary beat. These latter observations support the report of Cheung and Jahn (7) that cystic fibrosis serum does not cause ciliary dyskinesia but rather that change in beat pattern is a secondary effect of cytolysis. However, they did not observe cytolysis with either heterozygote or normal sera. In view of this variation in results, we decided to utilize the technique of Cherry et al. (6) to determine whether sera from individuals with cystic fibrosis, their parents (heterozygote sera), and control subjects were all equally cytotoxic to rabbit tracheal epithelium.

\section{MATERIALS AND METHODS}

\section{SERUM SAMPLES}

Blood samples from cystic fibrosis patients, parents, and normal individuals were obtained from several sources including the Cystic Fibrosis Center, University of Kentucky Medical Center, Lexington, KY, and the East Tennessee Children's Hospital, Knoxville, TN. Serum was obtained from whole blood by standard clinical methods. The serum samples were used immediately or frozen in sterile plastic tubes at $-70^{\circ} \mathrm{C}$ until used. In all, 10 cystic fibrosis (homozygote) sera, seven carrier (heterozygote) sera, and nine presumed normal sera were tested. Serum samples were tested for variation in $\mathrm{pH}$ and osmolarity after 2 -hr exposure to air because tests were conducted in open depression slides with unbuffered sera. Serum sample $\mathrm{pH}$ varied from an average of 7.9 $(0 \mathrm{~min})$ to $8.3(120 \mathrm{~min})$ after exposure to air for control serum (range, 7.5 to 8.5$)$, from $8.0(0 \mathrm{~min})$ to $8.3(120 \mathrm{~min})$ for heterozygote serum (range, 7.5 to 8.8$)$, and from $7.6(0 \mathrm{~min})$ to $8.0(120$ $\mathrm{min}$ ) for cystic fibrosis serum (range, 7.6 to 8.1 ). Osmolarity of all serum after $2 \mathrm{hr}$ exposure to air with 5 exceptions fell within the normal range of 277 to 299 mOsm as measured by an Osmette Precision Osmometer. Of the five samples not within normal ranges, one was a control serum, and three were heterozygote sera. Three of these were slightly hypoosmolar (267-268). Only one heterozygote sample was hyperosmolar (310). Thus, no significant differences could be detected between control, heterozygote, or cystic fibrosis sera with regard to either $\mathrm{pH}$ or osmolarity of sera samples either immediately after thawing or after $2 \mathrm{hr}$ exposure to air.

\section{EPITHELIAL EXPOSURE TO SERUM}

For this study, 218 tracheal rings from 17 New Zealand White rabbits were used. The animals were young adults and weighted from 2.7 to $4.1 \mathrm{~kg}$. Animals were carefully selected to be sure they were free of respiratory problems and killed by either air embolism or injection of $0.3 \mathrm{ml} / \mathrm{kg}$ of body weight of $\mathrm{T}-61$ Euthanasia Solution (National Laboratories Corp.). Tracheas were removed and rinsed in sterile $0.9 \%$ saline solution. Excess connective tissue 
was removed, and the tracheas were cut into rings approximately 1 to $2 \mathrm{~mm}$ thick. The rings were rinsed in two successive changes of saline for $10 \mathrm{~min}$ per rinse to remove any remaining blood or debris. During the rinse, the rings were checked for ciliary activity by phase contrast microscopy. Only those rings showing good activity were used. From the remaining rings, one was chosen at random as the untreated control for that experiment and fixed. Rings showing good ciliary activity were transferred to depression slides containing full-strength serum and placed in a covered Petri dish for exposure periods of $3,5,10,15,30$, and $60 \mathrm{~min}$ at room temperature. A presumed normal serum was designated as the standard serum which was run in every experiment for a total of 11 separate runs. This provided a reliably constant control to each analysis so that samples could be compared between tracheas and evaluated for damage.

\section{ELECTRON MICROSCOPY}

After exposure to sera, the tracheal rings were fixed in a mixture of one part $2.5 \%$ glutaraldehyde in $0.1 \mathrm{M}$ cacodylate buffer and two parts $1.0 \%$ osmium tetroxide in $0.1 \mathrm{M}$ cacodylate buffer $(\mathrm{pH}$ 7.4) in ice for one hr (15). Each ring was cut in half, one-half being prepared for transmission electron microscopy and the other half for scanning electron microscopy. Samples for transmission electron microscopy were dehydrated in a graded ethanol series and propylene oxide. After infiltration, the epithelium was dissected away from the underlying connective tissue and the cartilagenous ring and embedded in Epon 812 . Sections were cut with diamond knives on a Porter-Blum MT-1 ultramicrotome and stained with uranyl acetate and lead citrate (22). The sections were examined in a RCA EMU-3H transmission electron microscope.

Samples for scanning electron microscopy were dehydrated in a graded series of acetone and critical-point dried in a Bomar SPC-900 EX critical-point dryer. Specimens were mounted on aluminum stubs and coated with gold:palladium (60:40) in a Denton DV-515 SM vacuum evaporator. Specimens were examined in an ETEC Autoscan scanning electron microscope operated at $20 \mathrm{kV}$.

\section{RESULTS}

\section{ULTRASTRUCTURE OF CONTROL EPITHELIUM}

Rabbit trachea is lined by a layer of ciliated pseudostratified columnar epithelium resting on a basal lamina There are three primary cell types present: ciliated columnar cells, goblet cells, and basal cells. Ciliated columnar cells extend from the basal lamina to the lumen of the trachea. Characteristically, the cells possess cilia and microvilli on their apical borders. Goblet cells are specialized nonciliated columnar cells which secrete mucus. The basal cells located on the basal lamina are considered to be the generative cells of the trachea.

At the beginning of each experiment in this study, a control sample of trachea was examined to establish the condition of the epithelium. Examination with scanning electron microscopy showed the epithelium to have a slightly convoluted surface with distinct folds. Two prominent structures observed were cilia and microvilli. relative amounts of each were dependent upon the health of the animal at the time of use. Health was judged on respiratory sounds made by the animal just before termination, the presence or absence of mucus-like material in the trachea while dissecting it into individual rings, and ciliary activity observed by phase contrast microscopy examination just before use. Healthier animals appeared to have a surface covered with cilia and with few exposed microvilli. The majority of the tracheas were of this type. Examination of the epithelium by transmission electron microscopy revealed the internal organization of control epithelium to be normal. Ciliated columnar cells possessed a large oval nucleus that occupied the central portion of the cell. The endoplasmic reticulum appeared throughout the cell. It, along with the Golgi bodies and the perinuclear cisternae, was generally undilated. Mitochondria were seen throughout the cells but were concentrated in the apical regions. They appeared to be rounded to elongated in shape, with varying numbers of cristae. Cilia were normal, possessing the characteristic $9+2$ microtubule structure. Goblet cells also possessed a large nucleus that occupied most of the cytoplasm. The cell junctions of all cells appeared unaltered.

Treatment of tracheal rings with normal sera, including the standard serum, produced no significant alterations to the epithelium through $60 \mathrm{~min}$ exposure. The structure of the mitochondria, Golgi apparatus, and granular endoplasmic reticulum was normal. Cell junctions remained intact, and the appearance of the mucus droplets in goblet cells was consistent with that found in the untreated controls. Cilia and microvilli appeared normal, showing no signs of swelling or breakdown. A few desquamated cells were present on the ciliary surface. However, they were scattered, and no accumulations were seen. A few thin strands of mucus were present on the surface also, but the epithelial folds were clear of material. One normal serum sample did cause some damage to the epithelium comparable to that seen with some cystic fibrosis samples. In that case, the overall effect was similar to that seen after 15 minutes exposure to cystic fibrosis heterozygote serum.

\section{ULTRASTRUCTURE OF CYSTIC FIBROSIS AND HETEROZYGOTE} SERUM EXPOSED EPITHELIUM

The effect of cystic fibrosis and heterozgyote sera on rabbit tracheal epithelium was basically the same. The major variation was in terms of the time after exposure at which change occurred although during the early periods changes were similar. In epithelium treated with cystic fibrosis sera for $3 \mathrm{~min}$, small amounts of mucus from the apical regions of scattered goblet cells appeared on the surface (Fig. 1). A few desquamated cells were present at this time. After $5 \mathrm{~min}$ exposure, net-like regions of mucus began to form in the epithelial folds, apparently from the breakdown of secreted mucus granules a process which could be seen at various periods of exposure (Fig. 7). Mucus was also present as thin strands on the surface of the cilia, but this was not extensive during these early exposure periods. Epithelium treated with heterozygote sera followed the same general pattern although the times at which effects were observed differed from those for cystic fibrosis sera. Although $3 \mathrm{~min}$ exposure caused similar changes for both types of sera, the mucus release that occurred in the 5-min cystic fibrosis serum treated tissue did not usually occur until after 10 min exposure to heterozygote sera. At this time, mucus from goblet cells appeared in the epithelial folds. A few mucus strands were also evident on some ridges. After $10 \mathrm{~min}$ exposure to heterozygote sera, the goblet cells showed increased mucus release in the form of large apical projections from the goblet cells (Fig. 3 ). The mucus droplets appeared swollen in comparison with control tissue mucus granules and granule membranes appeared ruptured (Fig. 3). Some dilation of the granular endoplasmic reticulum of goblet cells was suggested.

Internal changes in ciliated cell structure appeared in both the 3-min cystic fibrosis and heterozygote serum exposed tissue. These changes were best examined in the epithelium exposed to heterozygote sera because the degree of alteration was not as great as with the cystic fibrosis sera. With heterozygote sera, the major effects in the early time periods ( 3 to $15 \mathrm{~min}$ ) appeared to be to the cell surface. Alterations consisted of ciliary resorption possibly by apical swelling of columnar cells, fusion of the cilia, disruption of the $9+2$ microtubule arrangement, loss of microtubule pairs, and lysing of the outer ciliary membrane. Resorption was the initial alteration, occurring after only $3 \mathrm{~min}$ exposure (Fig. 2). Apical regions of cells could be seen to contain numerous cross and longitudinal sections of ciliary axonemes. No indication of any comparable structures was evident in $3 \mathrm{~min}$ controls or for the 11 standard runs. In cross-section, the $9+2$ microtubule organization was frequently evident within the cytoplasm (Fig. 2). In other regions, the $9+2$ organization was disappearing, and areas of unorganized ciliary microtubules were observed. The cell surface at this time was intact, and mitochondria and other cellular 


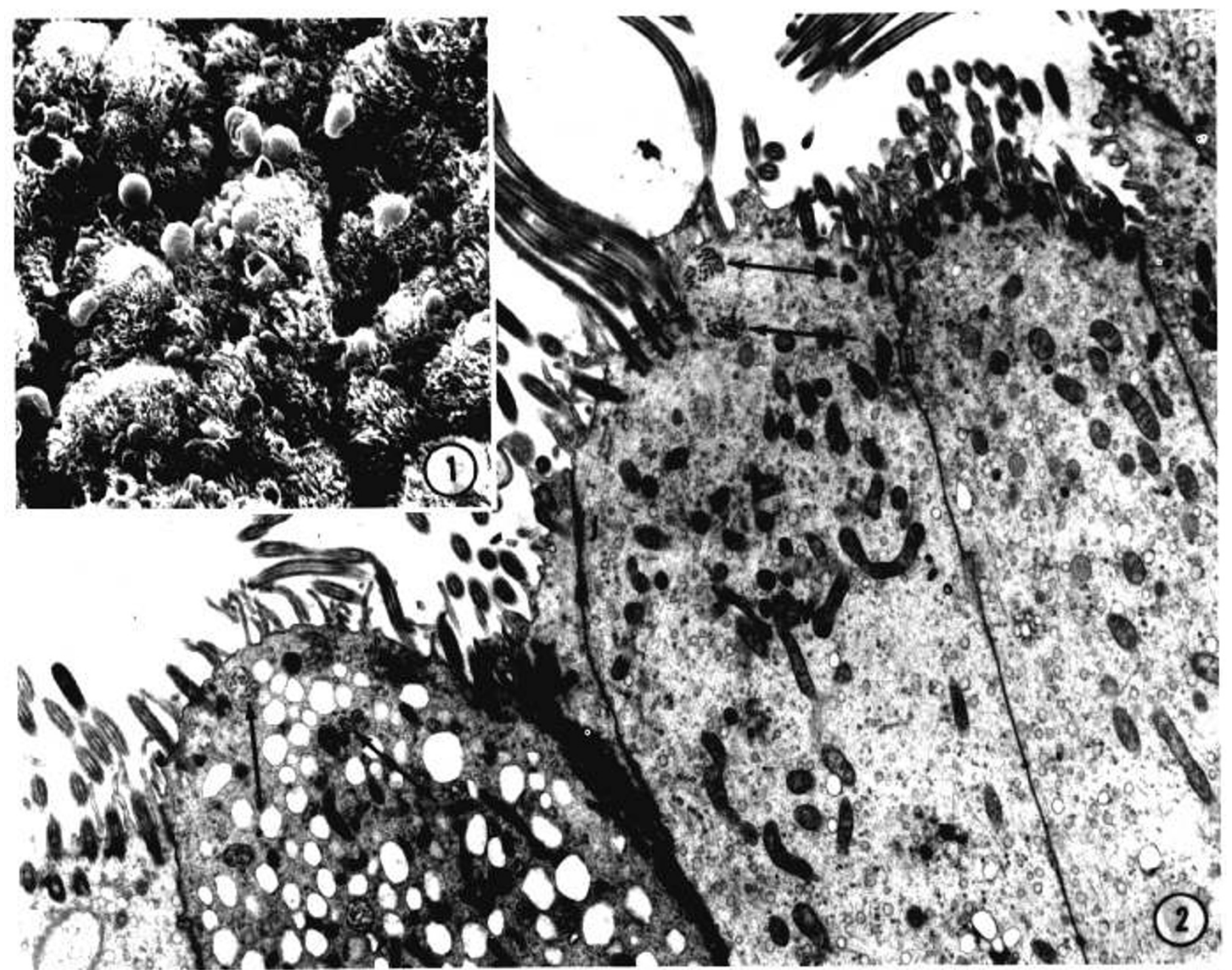

Fig, 1. Epithelium exposed for $3 \mathrm{~min}$ to cystic fibrosis serum. Mucus release from the apical regions of goblet cells (arrows) begin to appear. The epithelial folds are free of mucus. Comparable changes are seen after 10 min exposure to heterozygote serum $(\times 500)$

Fig. 2. Epithelium exposed for $3 \mathrm{~min}$ to heterozygote serum. In many cells, ciliary axonemes (arrows) are resorbed into the cytoplasm. Most axonemes retain their $9+2$ organization, but some disruption occurs. Mitochondria $(M)$ are normal, endoplasmic reticulum is dilated in some cells, intracellular junctions $(J)$ are intact, and the surface is generally free of debris. $(\times 9000)$.

organelles appeared normal. With increased exposure, the incidence of resorption seemed to peak (about 15 to 30 min exposure) and then decreased, possibly due to increased cell loss or internal degradation.

Alterations in ciliary structure were frequent. Fusion of cilia and loss of microtubule pairs was observed after only $3 \mathrm{~min}$ exposure and increased markedly through $60 \mathrm{~min}$ exposure to both abnormal sera. Ciliary fusion usually involved incorporation of 2 to 6 axonemes into a single membrane bound organelle. These fused cilia either remained intact to project from the cell or the axonemes became incorporated into the apex of the cell (Fig. 4) an enhancement of the effect seen in the $3 \mathrm{~min}$ exposed series. With increasing time, the number of axonemes incorporated increased (Fig. 5) and axonemal disorganization was more prominent. This may represent increasing swelling of the apex of ciliated cells due to exposure to both types of sera. Sites of fusion were also observed which contained more than 6 axonemes (Fig. 6). These larger groups also appeared after exposures of 15 to $60 \mathrm{~min}$. Within the fusion groups, disorganization of the $9+2$ microtubule pattern and loss of the central microtubule pair was also observed. Examination of longitudinal sections of fused cilia indicated that fusion progressed along the length of axonemes although it was not possible to establish whether fusion originated apically or basally along the ciliary shaft. In some a thickening of the ciliary membrane (Fig. 6, inset) was evident.

No other significant changes occurred in epithelium exposed to heterozygote sera until $60 \mathrm{~min}$. Again, results were variable, but many regions contained a thick mucus net over the ciliary surface with an increased number of loose cells either incorporated into the net or laying on top of it. Cilia could be seen protruding through the net, and regions lacking mucus were evident. These changes were comparable to those seen in tissue exposed to cystic fibrosis sera after $15 \mathrm{~min}$ (Fig. 7). In this figure, the breakdown of secreted mucus droplets to form the mucus net is evident. Also, after 60 min exposure to heterozygote sera, the largest number of areas containing mucus trapped cilia were observed. These were frequently in epithelial folds where the mucus net first formed. In addition, this appeared to be the site of the greatest number of altered cilia. Various degrees of alteration of the $9+2$ microtubule arrangement were evident. They included, in addition to the loss of the central microtubule pair described previously (Fig. 6, inset), general separation of the peripheral ciliary microtubules. Folds contained numerous normal cilia as well as scattered cilia whose peripheral microtubules were disorganized (Fig. 8). Separation of peripheral microtubules occurred between adjacent pairs, with the individual microtubule pairs remaining intact. Thus in cross-sec- 


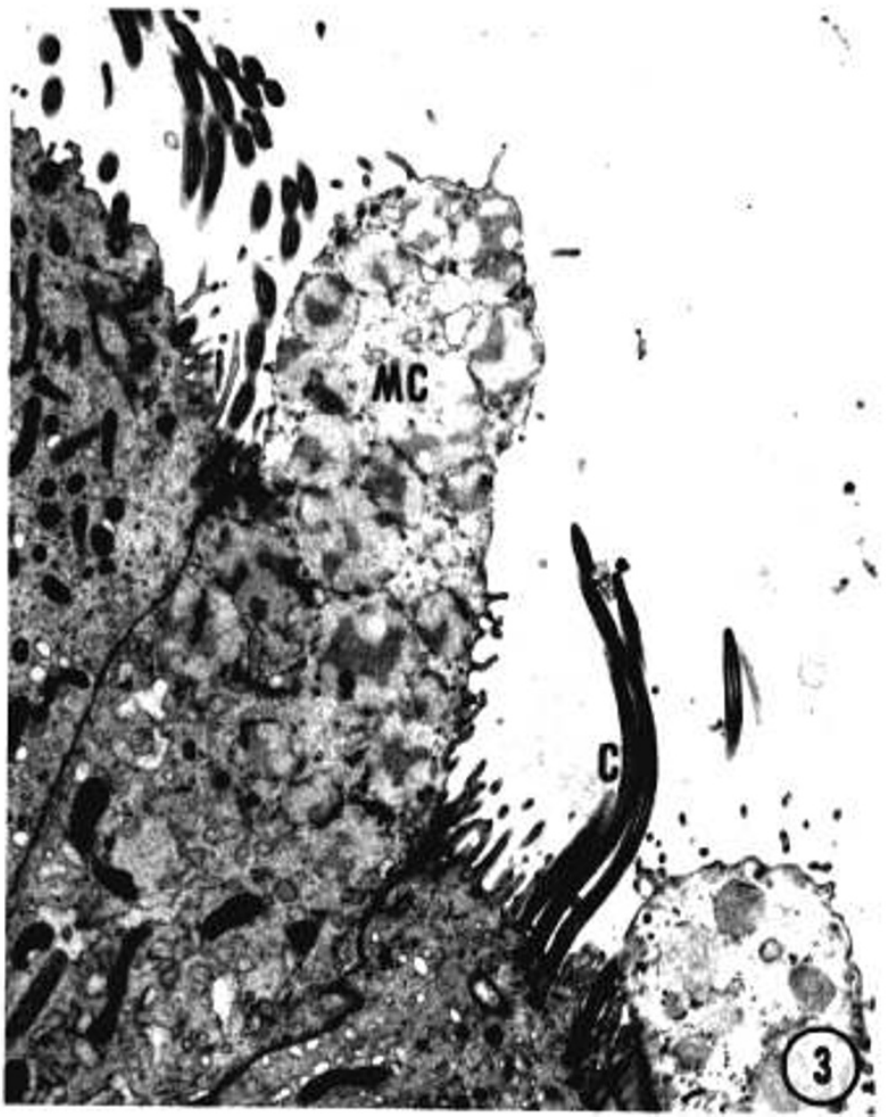

Fig. 3. Changes comparable to those in Figure 1 can be seen beginning at about $5 \mathrm{~min}$ exposure to heterozygote serum. The projecting goblet cell mucus $(M C)$ with disrupted granule membranes is evident. Most cilia $(C)$ appear normal although a resorbed cilium is present. Organelles appear normal. $(\times 6000)$.

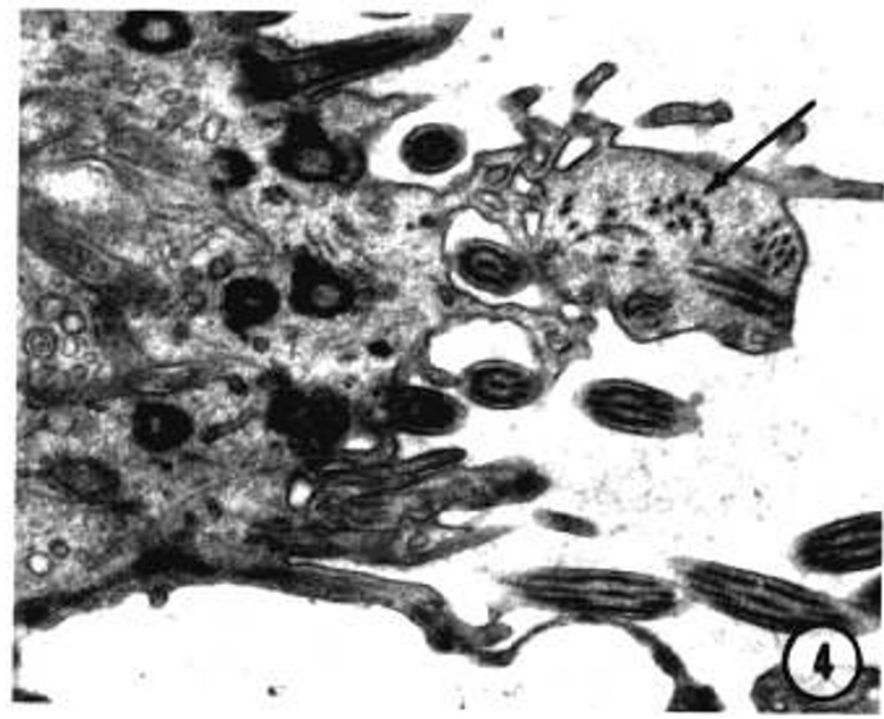

Fig. 4. Tissue exposed for $5 \mathrm{~min}$ to heterozygote sera. Fusion occurs between cilia and surrounding microvilli at the apical surface of a cell. The axonemal organization (arrow) is lost $(\times 14,000)$.

tion, it appeared that the axonemal organization was opening within the ciliary membrane. Examination of the normal appearing cilia from one of these regions suggested that microtubule substructure was modified. Although some cilia with distinct microtubule structures were present, many cilia seemed to have formed secondary cross-linkages which appeared as darkened microtubule centers within individual microtubules. These cross- linkages may represent an initial alteration to ciliary microtubule structure. Many areas of apparently normal cilia could still be observed at this time; thus, the effect is not universal to cilia at 60 $\min$.

During the exposure periods from 3 to $60 \mathrm{~min}$, most of the ciliary alteration induced by heterozygote sera were also observed with cystic fibrosis sera, the exception being lysis of the ciliary membranes which resulted in the formation of naked axonemes. This latter alteration was confined to epithelium exposed for 60 min to serum from individuals with cystic fibrosis. During the 3and 5-min exposures, serum from heterozygotes induced more

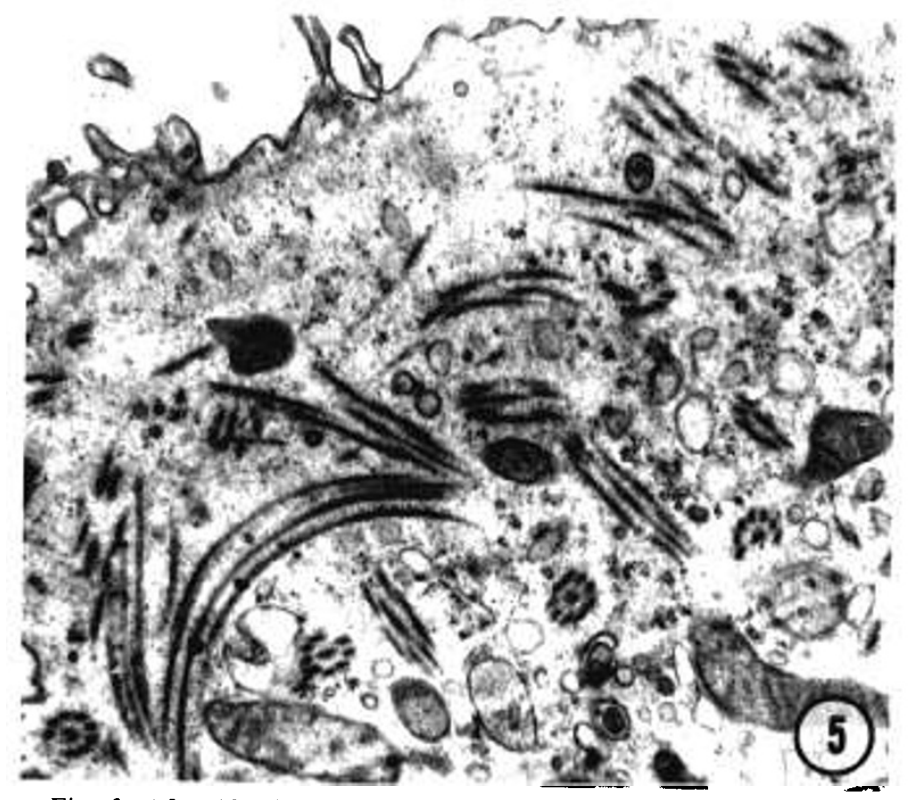

Fig. 5. After $10 \mathrm{~min}$ exposure to heterozygote serum, many axonemes have become incorporated into the apex of a cell and are breaking down $(\times 15,000)$.

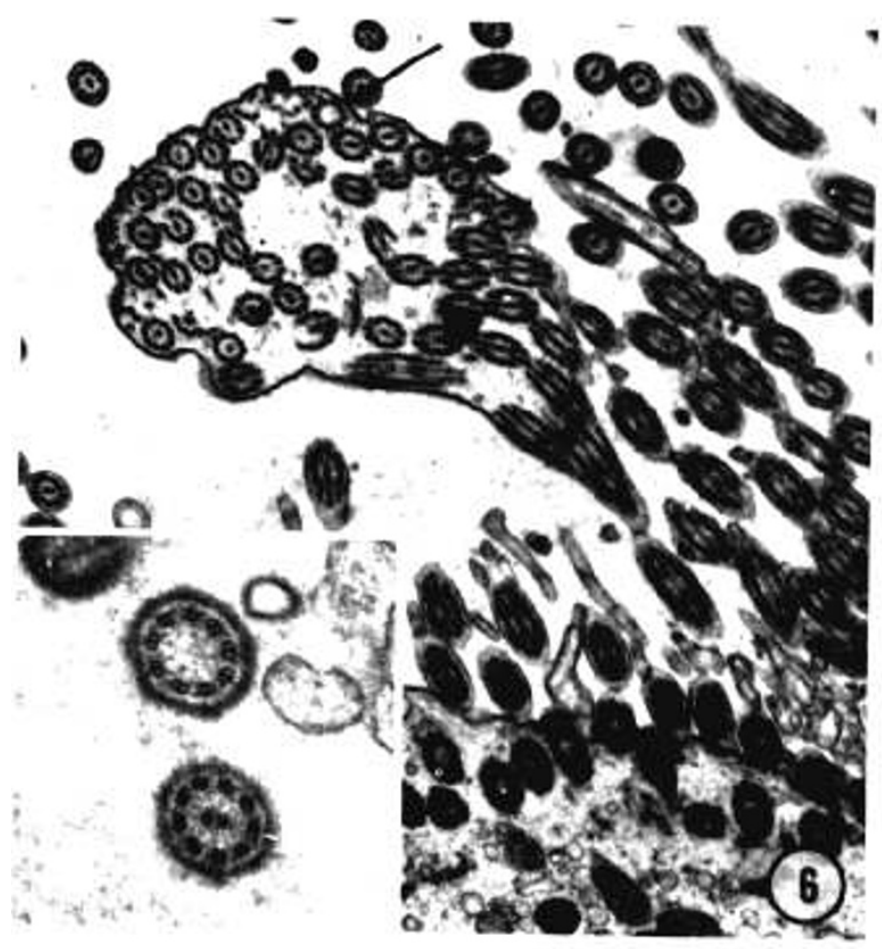

Fig. 6. A large group of fused cilia are seen in this micrograph from epithelium exposured to heterozygote sera for $15 \mathrm{~min}$. Many axonemes have lost their $9+2$ microtubule structure. An axoneme without its central tubules is indicated at the arrow. Inset, some cilia show only loss of central tubules and thickening of ciliary membranes $(\times 11,200$; inset, $\times 26,500)$. 


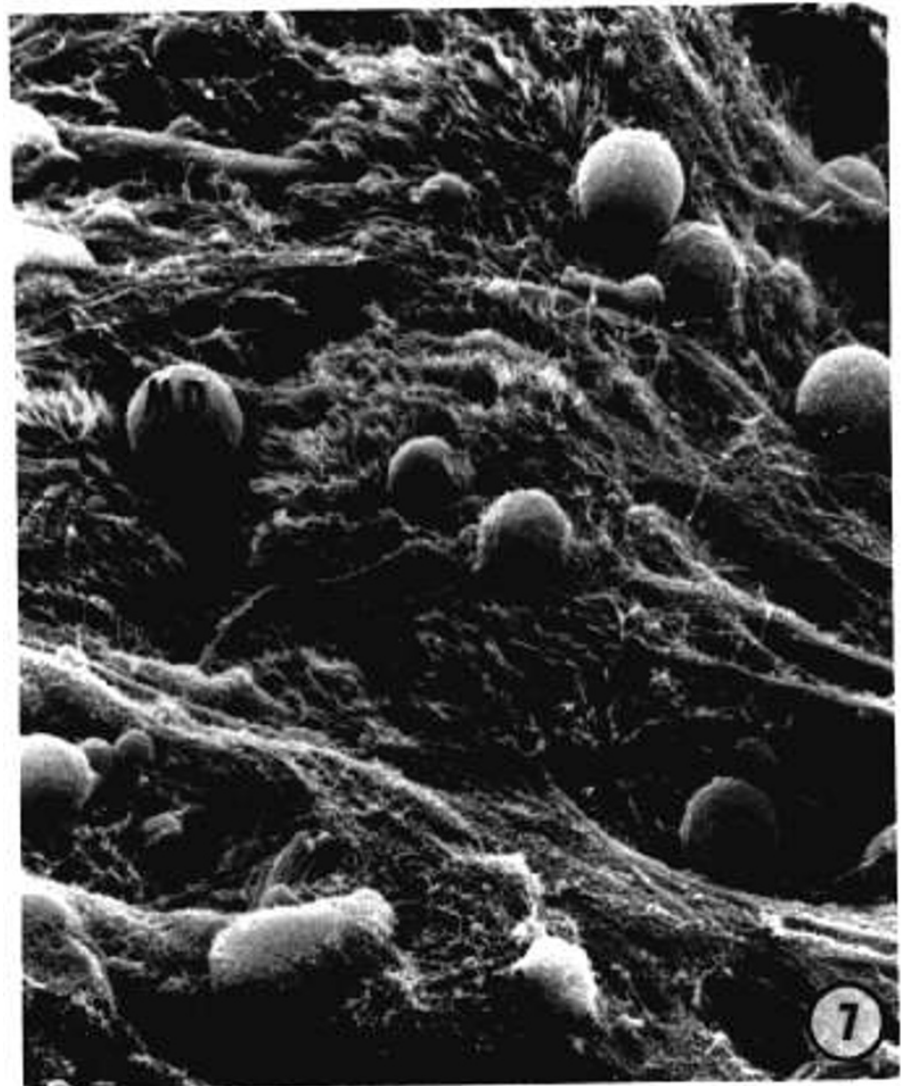

Fig. 7. Epithelium exposed to cystic fibrosis serum for 15 min siows changes comparable to those observed after $60 \mathrm{~min}$ exposure to heterozygote sera. Here, mucus droplets $(M D)$ are being released and are breaking down to form a fibrous mucus net. $(\times 1500)$.

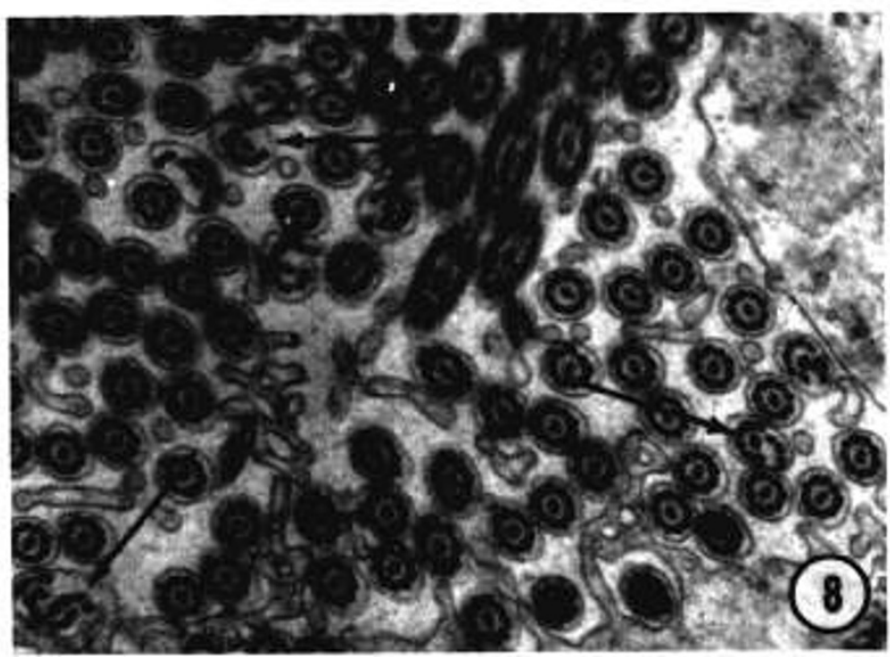

Fig. 8. Examination of an area such as that seen in Figure 10 reveals numerous cilia with altered microtubule arrangements (arrows) primarily as disruption of the outer doublets $(\times 14,000)$.

ciliary resorption and fusion than did cystic fibrosis serum, but overall damage was greater after exposure to cystic fibrosis serum (Fig. 10). After 15 min exposure, however, resorption was greater with serum from cystic fibrosis individuals.

More extensive alteration to epithelial cells was observed after exposure to cystic fibrosis sera for up to $60 \mathrm{~min}$. Prolonged exposure results in increased mucus secretion, being rather extensive at 15 min exposure (Fig. 7). As indicated previously, this was comparable to damage seen in epithelium exposed to heterozygote sera for $60 \mathrm{~min}$. Thirty-min exposure produced increased secretion over that seen in the 15 -min sample. The mucus strands seen in the 15-min sample had fused with other strands and free mucus droplets to produce a mucus net over approximately $50 \%$ of the ciliary surface. Desquamated cells attached to the mucus strands were incorporated into the net. Sixty-min exposure generally produced massive columnar cell loss and exposure of the basal cells (Fig. 9). In some areas, exposure of the basal lamina had also occurred.

All of the internal changes associated with the 3-min heterozygote serum exposed epithelium were found in tissue exposed to cystic fibrosis serum for $3 \mathrm{~min}$, but damage was much more extensive. Some columnar cells were swollen and contained a highly dilated endoplasmic reticulum network (Fig. 10). This swelling was greater than in comparable heterozygote serum exposed tissue. Cilia on these cells appeared swollen, but retained their $9+2$ microtubule structure. Resorption and fusion were not as prevalent as in the 3 -min heterozygote samples. Mitochondria had begun to take on slightly contorted shapes, particularly in the swollen cells, and many contained dense matrices, displaying little internal structure. Basal cells showed significant changes when compared to the 3-min heterozygote serum exposed tissue. Although some seemed unaffected, others contained swollen mitochondria and extreme distension of the perinuclear cisternae and possessed a large vacuole containing dark flocculent material. These changes continued up to $60 \mathrm{~min}$ exposure. After $60 \mathrm{~min}$ exposure, many cells were either lysed or severely damaged. A thick layer of mucus had been deposited on the surface of the cell layer, enclosing larger areas of cilia. Cilia trapped in the mucus layer were in various stages of disruption. Mitochondria in these areas were swollen, and in many, few cristae were visible. The changes induced after $60 \mathrm{~min}$ exposure to serum from cystic fibrosis individuals were characteristic of what one would expect from cells undergoing extensive cytolysis.

With the exception of one serum sample, examiantion of tissues exposed to sera from random control individuals for up to $60 \mathrm{~min}$ and to the standard serum run 11 separate times showed none of

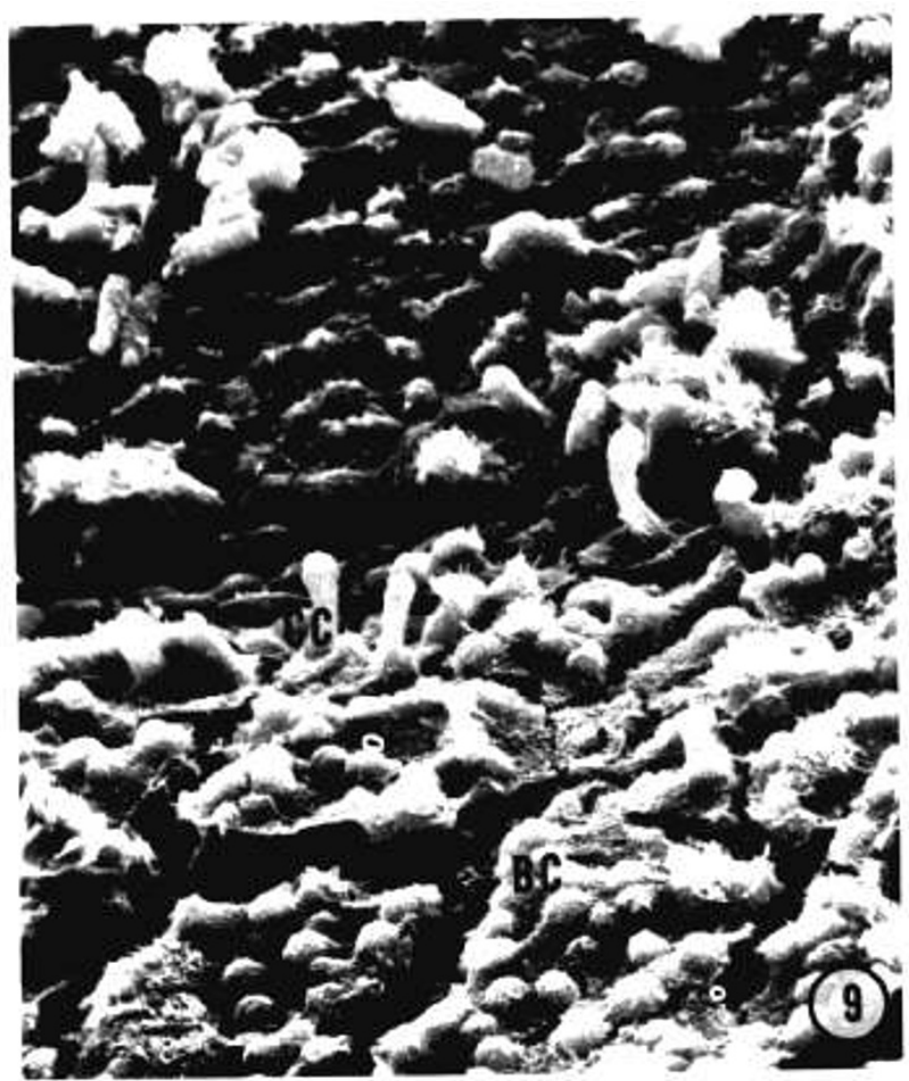

Fig. 9. In tissue exposed for $60 \mathrm{~min}$ to cystic fibrosis serum, extensive cell loss has occurred, exposing the basal cells $(B C)$. Only scattered columnar cells $(C C)$ remain $(\times 800)$. 


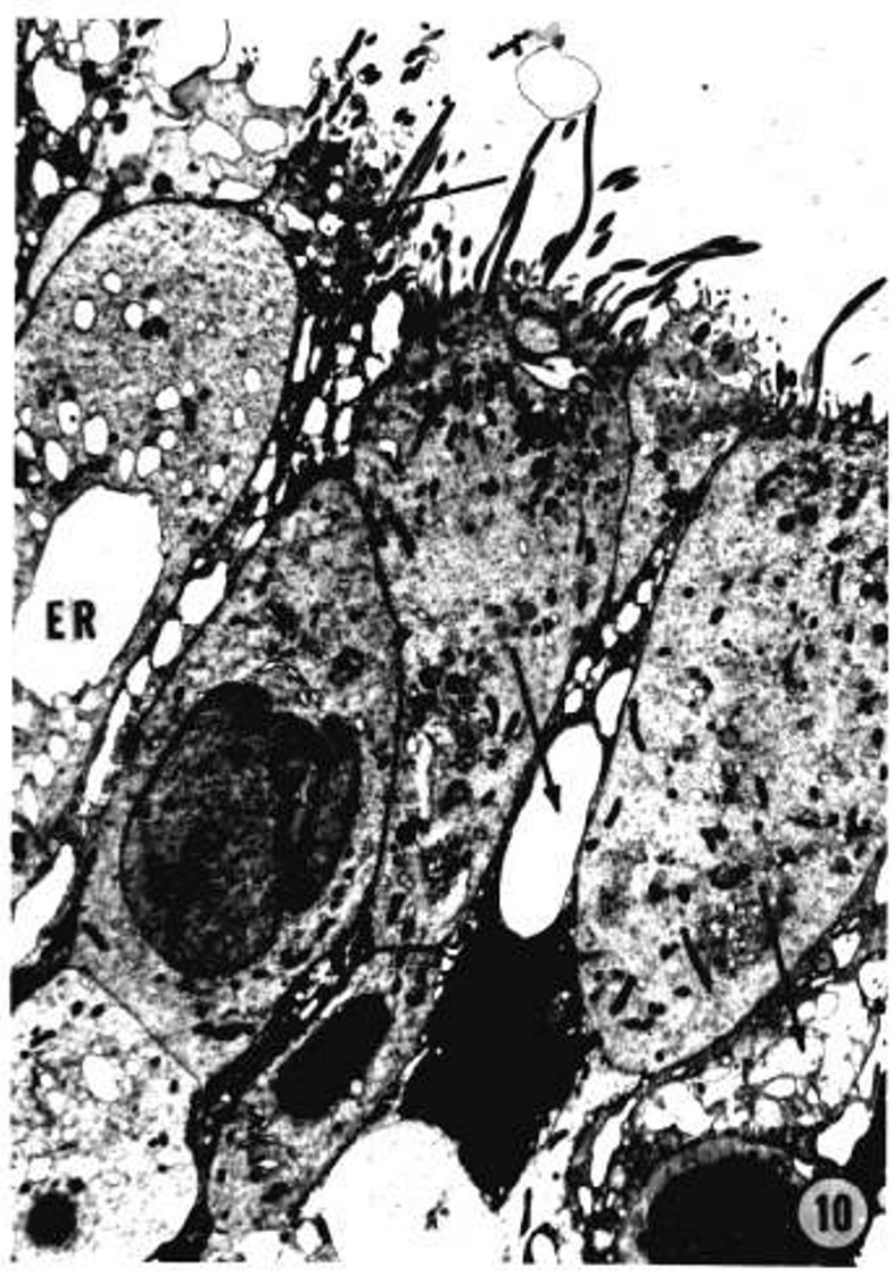

Fig. 10. After only 3 minutes exposure to cystic fibrosis serum, some cells show extensive swelling (arrows) particularly of the endoplasmic reticulum $(E R)(\times 2300)$.

the ultrastructural alterations described above. In one case, however, control serum induced changes comparable to those observed with the serum from heterozygous individuals. It is feasible that this sample represents an unidentifiable cystic fibrosis heterozygous individual. Because the observed changes did not occur in eight of nine control sera or any of the 11 repeats of the standard serum, it is evident that the ciliary changes observed were induced by a factor of factors in heterozygous and cystic fibrosis serum not found in normal serum. Neither do they represent normal alterations in rabbit tracheal epithelium or alterations from experimental manipulations.

\section{DISCUSSION}

The question of whether cystic fibrosis serum-induced ciliary dyskinesia is brought about by a direct effect of serum factor(s) on the ciliated cell or results secondarily from excess mucus secretion of goblet cells is still unresolved. Excess mucus production has been considered by several investigators to be the principal factor influencing ciliary beat $(2,12,13)$. Our data suggest that the primary effect may be on the ciliated cell, with secondary changes being induced by goblet cell secretion.

We observed apical swelling of some ciliated cells after only 3 min exposure to both types of sera. At that time, mucus granules project from goblet cells but secretion is not sufficient enough to interfere with ciliary function. Furthermore, it seems unlikely that mucus secretion itself would cause apical swelling of ciliated cells. Mucus secretion to a level necessary to induce mucus net formation does not occur until 30 to $60 \mathrm{~min}$ after exposure to heterozygous serum and $15 \mathrm{~min}$ after exposure to cystic fibrosis serum, in both cases some time after the appearance of most types of ciliary alteration. Thus, we feel that serum factor(s) induced apical swelling, and the alteration of ciliary structure may be the initial cause of ciliary dyskinesia. Studies of Verdugo et al. (23) in part support this interpretation. These investigators observed that $10 \%$ cystic fibrosis serum caused an increase in ciliary beat frequency followed by a rapid arrest of ciliary beat when measured by a new and highly accurate method of laser light-scattering spectroscopy. Furthermore, their measurements were of serum effects on ciliated cells as outgrowths from tracheal explants. Cilia of cells obtained in this manner can be viewed without interference from cilia of adjacent cells, and outgrowths lack mucus-secreting goblet cells (19). Thus, their data demonstrate cystic fibrosis serum induced rate change in the absence of mucus. Their system is not capable of measuring loss of phase coherency (dyskinesia), but preliminary studies in our laboratory utilizing a similar system (16) capable of measuring loss of phase coherency also suggest that dyskinesia occurs before formation of the mucus net. It seems likely, therefore, that ciliary dyskinesia results from apical swelling of ciliated cells, resorption of ciliary axonemes, and some fusion of cilia. Furthermore, these changes may be induced by a factor(s) in both cystic fibrosis and heterozygote sera and may also be separated in time from mucus secretion of goblet cells.

The dyskinesia factor(s) may also be acting on goblet cells to promote the increased mucus secretion observed by numerous investigators $(2,5,12,13)$. The later events of ciliary fusion may result from a combination of serum factor effects on ciliated cells and mucus net formation. The separation of adjacent pairs of ciliary microtubules after 60 min exposure to heterozygote serum may result entirely from mechanical stress caused by the trapping of normally active cilia in a thick mucus net.

Several other investigators have examined the effects of serum from individuals both heterozygous and homozygous for cystic fibrosis on cilia using a variety of models. Adshead et al. (1), in studying freshwater mussel gill cilia, reported that diluted cystic fibrosis serum produced two effects on cilia. Shock-stopped cilia (those which quit beating immediately) retained their normal diameters but lost all signs of internal microtubule structure. However, control serum produced the same effect and ciliary recovery occurred after a brief period in both sera and appeared normal. Slow-stopped cilia appeared shortened but retained their axonemal structure. No ciliary changes comparable to those described by Adshead et al. (1) were observed in this study, although cell loss, tissue disruption, and mucus accumulation reported by others $(1,12)$ were observed. Baur et al. (2) found no ultrastructural change in oyster gill cilia. Bogart et al. (4) investigated the effects of serum from cystic fibrosis individuals, but not from the heterozygotes, on rabbit tracheal explants $48 \mathrm{hr}$ old, utilizing transmission electron microscopy. They found no changes in ciliary ultrastructure under the conditions used in their study. We observed that cystic fibrosis serum caused extensive ciliary and cellular damage by 3 to $5 \mathrm{~min}$ after exposure followed by rapid desquamation of necrotic cells. Ciliary alterations under these conditions are often obscured by the more extensive damage and desquamation and may have been overlooked by Bogart et al. (4) because their micrographs show primarily intact cells. We found the more subtle changes to be detectable with heterozygote serum which was not used by Bogart et al. (4).

Some ciliary changes similar to those described in this study have been observed under a variety of conditions including human bronchial epithelium obtained during surgery or at "immediate autopsy" mainly from smokers (17) and in hamsters exposed to respiratory carcinogens (14). The similarities include fused cilia and intracytoplasmic axonemes. Changes observed in this study but not previously reported include opening of the axonemal organization within an otherwise intact cilium and increased densities within ciliary microtubules. Thus, the observed ciliary changes although not being entirely unique to cystic fibrosis and heterozygous sera, do represent changes brought about by rapid ( 3 to $5 \mathrm{~min}$ ) damage to ciliated cells by these two types of sera. What does seem significant, however, is that these two sera appear 
capable of altering ciliary structure in tracheal epithelium from carefully selected normal healthy rabbits although control (normal) serum does not cause these changes.

This study clearly shows that contrary to the observations of Cherry et al. (6), normal sera causes little it any damage to the epithelial layer. Some mucus and a few loose cells were seen, but only in one case, was extensive damage evident. This abnormal control serum sample produced mucus accumulation, swollen cilia, and some cell loss equivalent to damage seen in tissue exposed for $15 \mathrm{~min}$ to heterozygote serum. The occurrence of the heterozygote in the population is approximately 1 in 25; therefore, the chances of obtaining a heterozygous individual as a control subject is feasible.

The mode of action of factor(s) in cystic fibrosis and heterozygote sera is still open to speculation. Studies have shown that calcium ionophore A23187 induces a response in rabbit tracheal explants similar to cystic fibrosis serum. These similarities include both ciliary dyskinesia $(3,11)$ and goblet cell mucus secretion $(10)$. Furthermore, by chelating the calcium in cystic fibrosis serum with [ethylenbis(oxyethenenitrilo)]tetraacetic acid, dyskinesia (3) and excess mucus secretion (10) can be inhibited. Thus, a factor(s) may be present in the serum from persons with cystic fibrosis and their parents which simulates the ability of calcium ionophore A 23187 to raise the intracellular level of calcium. This influx of calcium into both ciliated columnar and goblet cells may be responsible for the types of ultrastructural alterations observed in this study. They may further account for changes in organization of ciliary beat (16) and shift in beat frequency (23) as well as for increased goblet cell mucus secretion.

Schanne et al. (20) suggest that agents which alter membrane function (including calcium ionophore A 23187) may allow for an influx of extracellular calcium into the cell resulting in cell death. In the absence of extracellular calcium, no appreciable cell death was observed. The cytolysis observed in this study and by Cheung and Jahn (7) and others after 60 min exposure to cystic fibrosis serum may represent calcium-dependent toxic cell death. Thus, the primary effect of the dyskinesia factor(s) may be to alter membrane permeability to certain ions and should be the focus of future studies on cystic fibrosis.

\section{REFERENCES AND NOTES}

1. Adshead, P. C., Martinez, J. R., Kilburn, K. H., and Hess, R. A.: Ciliary inhibition and axonemal microtubule alterations in freshwater mussels. Ann. N. Y. Acad. Sci.. 25.3: 192 (1975).

2. Baur. P. S.. Brinkley. B. R.. and Bowman. B. H.: Effects of cystic fibrosis serum ciliary inhibitor on oyster gill ultrastructure: analysis by scanning and transmission electron microscopy. Tex. Rep. Biol. Med., 34: 155 (1976).

3. Bogart. B. I. Conod. E. J., and Conover. J. H.: The biologic activities of cystic fibrosis serum. I. The effects of cystic fibrosis sera and calcium ionophore A23187 on rabbit tracheal explants. Pediatr. Res., 11: 131 (1977).

4. Bogart. B. I., Conod. E. J., Gaerlan, P. F., and Conover. J.: The biologic activities of cystic fibrosis serum. II. Ultrastructural aspects of the effect of cystic fibrosis sera and calcium ionophore A23187 on rabbit tracheal explants. Pediatr. Res. 12: 15 (1978).
5. Bowman. B. H., Lockhart. L. H., and McCombs, M. D.: Oyster ciliary inhibition by cystic fibrosis factor. Science (Wash. D. C.), 164: 325 (1969).

6. Cherry, J. D., Roden, V. J., Rejent. A. J., and Dorner. R. W.: The inhibition of ciliary activity in tracheal organ cultures by sera from children with cystic fibrosis and control subjects. J. Pediatr., 79 : 937 (1971).

7. Cheung. A. T. W., and Jahn. T. L.: High speed cinemicrographic studies on rabbit tracheal (ciliated) epithelia: cytolytic effects of cystic fibrosis serum on tracheal epithelial cells. Pediatr. Res., 7: 220 (1976).

8. Christensen. J and Norrevarg. A. Studies on the effect of CF serum on fresh tissue from Drejssensia gills, oyster gills, and rabbit tracheal mucosa. Proceedings of the Fifth International Cystic Fibrosis Conference, Cambridge. England, Cystic Fibrosis Research Trust 49 (1969).

9. Conover, J. H. Bonforte, R. R. Hathway, P.. Paciuc, S.. Conod, E. J., Hirschhorn, K., and Kopel. F. B.: Studies on the ciliary dyskinesia factor in cystic fibrosis. I. Bioassay and heterozygote detection in serum. Pediatr. Res., 7: 220 (1973).

10. Conover, J. H., and Conod. E. J.: The influence of cystic fibrosis serum and calcium on secretion in the rabbit tracheal mucociliary apparatus. Biochem. Biophys. Res. Commun., 83: 1595 (1978).

11. Conover, J. H.. Conod, E. J., Gaerlan. P. F., and Bogart, B. I.: Calcium influx and cystic fibrosis. Lancet, 2: 1362 (1976).

12. Czegledy-Nagy, E., and Sturgess, J. M.: Cystic fibrosis: effects of serum factors on mucus secretion. Lab. Invest.. 35: 588 (1976).

13. Gabridge. M. G., Bright. M. J., Agee, C. C., Nickerson. J. M., and Henderson. N. S.: Development of an improved tracheal explant bioassay for the detection of the ciliary dyskinesia factor in cystic fibrosis serum. Pediatr. Res.. 13: 31 (1979).

14. Harris, C. C. Kaufman, D. G., Jackson, F., Smith. J. M., Dedrick, P., and Saffiotti. U.: Atypical cilia in the tracheobronchial epithelium of the hamster during respiratory carcinogenesis. J. Pathol.. 114: 17 (1974).

15. Kennedy, J. R. and Allen. P. L.: Effects of cigarette smoke residue on rabbit tracheal epithelium in organ culture. Arch. Environ. Health, 34: 5 (1979).

16. Kennedy, J. R., and Duckett. K. E.: An accurate method for measuring ciliary beat and its application to tracheal epithelium. J. Cell Biol.. 83(Part 2): 182 (1979).

17. McDowell, E. M., Barrett, L. A., Harris, C. C., and Trump, B. F.: Abnormal cilia in human bronchial epithelium. Arch. Pathol. Lab. Med.. 100: 429 (1976).

18. Posselt. H. G., and Bender, S.: Heterozygote testing in cystic fibrosis. Experimental studies with cilia of the mussel Dressensia polymorpha. Z. Kinderheilkd., 100: 93 (1971).

19. Ranyard, J. R., Kennedy, J. R., Vaughan. G. L., and Duckett. K. E.: Morphology of ciliated outgrowths from cultured rabbit tracheal epithelial explants. J. Cell Biol., 83:(Part 2): 113 (1979).

20. Schanne, F. A. X., Kane, A. B., Young, E. E., and Farber, J. L.: Calcium dependence of toxic cell death: a final common pathway. Science (Wash. D. C.). $206: 700$ (1979).

21. Spock, A.. Heick. H. M. C.. Cress, H., and Logan. W. S.: Abnormal serum factor in patients with cystic fibrosis of the pancrease. Pediatr. Res.. 1: 93 (1967)

22. Venable, J. H., and Coggeshall, R.: A simplified lead citrate stain for use in electron microscopy. J. Cell Biol., 25: 407 (1965).

23. Verdugo, P., Hinds, T. R., and Vincenzi, F. F.: Laser light-scattering spectroscopy: preliminary results on bioassay of cystic fibrosis factor(s). Pediatr. Res.. 13: 131 (1979).

24. Serum samples were obtained through Dr. H. David Wilson and Dr. Jacquline Campbell, Cystic Fibrosis Center. The University of Kentucky Medical Center. Lexington. Kentucky and Dr. Donald Hatcher. East Tennessee Children's Hospital, Knoxville. TN.

25. The present address of Patricia L. Allen is Electron Microscope Center, 1225 Gardner Hall, North Carolina State University. Raleigh. NC 27507 (USA).

26. Requests for reprints should be addressed to: John R. Kennedy, Department of Zoology, University of Tennessee. Knoxville. TN 37916 (USA).

27. This research was supported in part by the Jimmy Durante Childrens Fund (Smoky Mountain Aerie No. 2698. Fraternal Order of the Eagles) and by a biomedical support grant from the National Institutes of Health.

28. Received for publication October 26, 1979.

29. Accepted for publication February 21. 1980 